\title{
Review on Recent Development Micro Gas Turbine -Trigeneration System and Photovoltaic Based Hybrid Energy System
}

\author{
MRR Chand ${ }^{1, a}$, H.Ibrahim ${ }^{1}$, Z.Azran ${ }^{2}$, A.Arshad ${ }^{1}$, F.Basrawi ${ }^{1}$ \\ ${ }^{1}$ Faculty of Mechanical Engineering, University Malaysia Pahang, 26600 Pekan, Pahang Malaysia \\ ${ }^{2}$ Faculty of Health Science, International Islamic University Malaysia, 26000, Kuantan, Pahang, Malaysia
}

\begin{abstract}
Research on distributed power generation as an alternative method to the conventional power generation system continue to be developed to improve its commercialization capabilities. The cogeneration system and trigeneration system are technological improved alternatives in distributed generation where they offer enhancement and reliability in term of efficiency, emission performances and economic benefits. However, it is more feasible to implement the trigeneration system for most commercial and domestic distributed generations as the cooling demand is deliberately high compared to heating demand especially in hot and humid climate locations. Moreover, micro gas turbine is observed to be a beneficial prime mover in cogeneration and trigeneration system based on several criteria such as ability on acquiring high heat to power ratio characteristic as well as lower greenhouse gas emission. On the other hand, the role photovoltaic in building integrated system provides opportunities for renewable energy system engagement in trigeneration based distributed generation systems. This paper emphasize on summarizing the research work perform on cogeneration system or trigeneration system in hybrid mode with photovoltaic. There are also preceding sections on overviewing the state of art of cogeneration system and the trigeneration system as well as photovoltaic technologies in power generation.
\end{abstract}

\section{Introduction}

The IEA report on the global $\mathrm{CO}_{2}$ emissions in year 2014, reflects positive pronounced effect on the effort of mitigating the climate change and improvisation of power generation technologies. The emission levels were broad constant from serious exaggeration hiked to 32.3 billion tons as reported in year 2013 [1]. However, magnifying the permanent shortcomings of conventional power generation system such as its inefficiency power generations, high levels of emissions as well as transmission loses and costs, diverging into new power generation technologies such as smart grid based distributed system are much anticipated. Encountering the shortcomings through introducing integrated system called cogeneration system (CGS) and trigeneration system (TGS) had yielded in way of obtaining higher efficient system with less system loses, reduced emission and conveniences in applications wise [2, 3].

It was estimated that the CGS and TGS system would reduce the global $\mathrm{CO}_{2}$ emissions by $10 \%$ that is 950 $\mathrm{Mt} /$ year by the year 2030 [4]. Technologies development also had enhanced the market capabilities of CGS and TGS system in mini and micro scaled, since the inventions of smart grid distributed generations [5]. Currently, the Germans lead the CGS and TGS utilization in power generation by $22 \%$, followed by Poland and Demark where $46 \%$ of Denmark power generations were contributed by the CGS and TGS systems [6]. Implanting renewable energy based systems [7], integrating low emission prime movers in a way of reducing fuel consumptions, improvisation of current conventional system, instilling awareness as well as imposing policies and invectives are measures that able to assist further reduction on emission level in power generation sectors [8].

On the other hand, renewable energy system (RES) technology is also promoted as a sustainability solution on encountering the drawback of the conventional power system. Photovoltaic (PV) technology which converts solar energy into electricity is adopted as promising source of energy where it provide reliability in reducing the emission level in the absence of mechanical parts. Furthermore, the ability of PV to be building integrated provide suitability in distributed power generation application [9]. However, the intermittency issue of PV has led to research and development in hybrid based system where integration with CGS and TGS provide opportunity in developing system which is efficient and economical promising [10].

Hence, this paper emphasis on providing review on research work performed under the scheme of PV and CGS or TGS hybrid based system. System design, analysis and optimization as well as recommendation for future work for latter system are presented in this paper. There are preceding elaboration included on the state of art of CGS,

\footnotetext{
${ }^{\text {a }}$ Corresponding author: rizdwan@ hotmail.com
} 
TGS and PV where prime movers technology as well as waste heat utilization technology are discussed in detail.

\section{Overview on CGS and TGS}

CGS are engineered through integrating prime movers and exhaust heat recovery units, operating to provide both electrical power and thermal energy simultaneously. Henceforth, the thermal energy output are utilized for domestic water heating, space heating or in any industrial process which requires heat input such as pulp process in paper industry, food fermentation and brewing process in food industry, petroleum as well as in refining process $[11,12]$. A CGS plant attains the ability to perform a high efficient energy conversion up to $80 \%$ of fuel energy compared to conventional power plant which converts an average of $30 \%$ to $35 \%$ of fuel energy $[13,14]$. However, in most application heat requirement is fairly seen to be fluctuating and low depending on the climate. The shortcomings of CGS in term of its inadequacy in fulfilling the thermal requirement in most end use demand leads to advance energy utilization technology where conversion of thermal energy into cooling energy is seen to be more reliable.

Henceforth, the idea of including a thermally activated equipment to utilize exhaust heat for district cooling has assisted in the development of an advanced system called TGS. TGS is a system that able to provide power as well as heat and cooling energy simultaneously has broaden the application of on-site power generations especially for commercial buildings such as office buildings and hospitals as the requirement of space cooling are extremely high. Indeed, the TGS system reduce the pay back periods and improve the prime movers operations as there were more higher load demand through reducing partial operations[15]. From economic stand of view, the capital cost of TGS system is higher compared to any other power generations technologies, however, considering several factors such as electrical efficiency of prime movers, energy price and electrical price, TGS will be favourable in some cases [16]. Both CGS and TGS competent in providing an overall system efficiency up to $60 \%$ to $80 \%$ and $70 \%$ to $90 \%$ respectively. It is higher compared to conventional power generation system where the recorded efficiency is between $39 \%$ to $47 \%$ for coal based power plants, $38 \%$ to $44 \%$ for oil based power plants and $54 \%$ for combine cycle gas turbine (CCGT).

\subsection{Prime Movers and Waste Heat Recovery Technologies}

The majority of prime mover technologies are heat engines that convert chemical energy in fuel into electricity through combustion with the exception for fuel cell which converts fuel energy electrochemically. Common prime movers in distributed generations are reciprocating engines which include diesel generator and gasoline generator, MGT fuel cells and sterling engines. Table 1 display the comparison of several parameters involving technical performances, economics and emission characterises for TGS applications in between MGT, reciprocating engines and fuel cells. Reciprocating engines are the spark ignition Otto-cycle engines and the compression ignition Diesel-cycle engine. Reciprocating engines offer several advantages in power generation such as high efficiency, fast start up which is suitable for peak shaving and back up applications, good partial operation performances as well as operating on low pressure gas. However, narrowing the application particularly into CGS and TGS, reciprocating engines suffer several downsides such as low exhaust temperature which lead to limitation in heat utilization application as well as high emission and noise level.

Reciprocating engine such as natural gas engine and diesel engine releases $60 \%$ to $70 \%$ of waste heat during its operation where $45 \%$ to $50 \%$ are recovered through jacket cooling water and lube oil cooling system and the remaining in the form of exhaust gases. The temperature of waste heat ranges from $85^{\circ} \mathrm{C}$ to $100^{\circ} \mathrm{C}$ from the engine jacket coolant as well as the $380^{\circ} \mathrm{C}$ to $540^{\circ} \mathrm{C}$ contributed by the exhaust gases. However, only $110^{\circ} \mathrm{C}$ of hot water or low pressure steam up to 400psig able to extracted from the reciprocating engines. The common mechanism used for exhaust heat recovery are close loop cooling system, ebullient cooling system, heat exchanger and boiler. The Closed-loop cooling system and ebullient cooling system technologies are used to extract the waste heat from engine jacket coolant whereas heat exchangers are used for exhaust heat recovery. The waste heat are delivered in the form of hot water or steam depending on the targeted area of applications.

On the other hand, the type of acknowledged fuel cell technologies for CGS and TGS are PEMFC, PAFC, MCFC and SOFC where currently the total installed capacity of CGS employing fuel cell are 83.6MW. PEMFC and PAFC produce low temperature heat mostly below $100^{\circ} \mathrm{C}$ which is appropriate for space heating and water heating. Fuel cells have extremely low emission and high efficiency compared to other prime movers as there is no fuel combustion process. Other advantages of the fuel cell include low noise frequency, high partial load performances and fuel flexibility as well as modular design. However, economic wise, fuel cell technologies require higher capital cost than any other prime mover that further upsurge the payback period due to low-volume custom production as well as additional cost involved in power conditioning. In addition, the fuel cells requires longer startup period with at least 3 hours to 2 days period required where feasibility in peak shaving application and back up application are lower.

MGT is classified as a small gas turbine with power generation capability ranging from $25 \mathrm{~kW}$ to $400 \mathrm{~kW}$, and which operates based on regenerated Brayton's Cycle with additional heat recovery heat exchanger called recuperator [17].The MGT units require lesser maintenance compared to reciprocating engines thanks to air bearing design that avoids any activities of oil lubrications and in addition there is no necessity. In additional cooling system as the atmospheric air provide the cooling needs [18]. Other merits of MGT over the reciprocating engines include less moving parts, lower emissions, small size and lightweight 
Table 1. The comparison of various CGS and TGS prime movers

\begin{tabular}{|c|c|c|c|c|}
\hline Parameters & DE & N-GE & MGT & Fuel Cell \\
\hline Size (MW) & $0.05-5$ & $0.05-5$ & $0.025-0.25$ & $0.2-2$ \\
\hline Electrical Efficiency (\%) & $30-50$ & $25-45$ & $20-30$ & $40-70$ \\
\hline CGS Efficiency (\%) & $77-80$ & $77-80$ & $63-70$ & $55-80$ \\
\hline CGS Output (Btu/kWh) & 3400 & $1000-5000$ & $4000-15000$ & $500-3700$ \\
\hline Start-up Time & $10 \mathrm{sec}$ & $10 \mathrm{sec}$ & $60 \mathrm{sec}$ & $3 \mathrm{hrs}-2 \mathrm{days}$ \\
\hline CGS installation Cost (\$/kW) & $800-1500$ & $800-1500$ & $500-1300$ & $>3000$ \\
\hline NOx (lb/MWhr) & $3-3.3$ & $2.2-2.8$ & $0.4-2.2$ & $<0.02$ \\
\hline
\end{tabular}

fuel flexibilities, longer lifetime, less noise and higher heat outputs[19] . Correspondingly, MGT also exhibit better performance on economic prospect and operation start up time in contrast to fuel cell technologies. Application wise, MGT acquiring the ability to be implemented in peak shaving, grid connected, back up auxiliaries and in CGS and TGS [20].

In term of waste heat recovery, MGT delivers high quality exhaust gases with high oxygen content up to $15 \%$ which is suitable for direct utilization. Furthermore, the utilization of MGT in CGS and TGS are further enhanced by the fact that the system exhaust heat temperature ranges from $260^{\circ} \mathrm{C}$ to $350^{\circ} \mathrm{C}$ with $\mathrm{CGS}$ output as high as $4000 \mathrm{Btu} / \mathrm{kWh}$ to $15000 \mathrm{Btu} / \mathrm{kWh}$ which is suitable for direct fired absorption chiller as well as other industrial process Commonly, the exhaust heat is transferred to heat water by means of heat exchanger mechanism. Fig 1 shows the useable heat temperature range of various prime movers where the fuel cell acquires a wider range and highest temperature to be utilized in CGS and TGS. However, economically, MGT offers better useable heat temperature range compared to reciprocating engines and fuel cell. In both TGS and CGS the exhaust heat recovered can be utilized for various heating application. In both TGS and CGS the exhaust heat recovered can be utilized for various heating application. Moreover, the recovered waste heat also requires capability for application for thermally activated equipment for space cooling such as absorption chillers, adsorption chiller, liquid and solid desiccant cooling as well as ejector cooling [21].

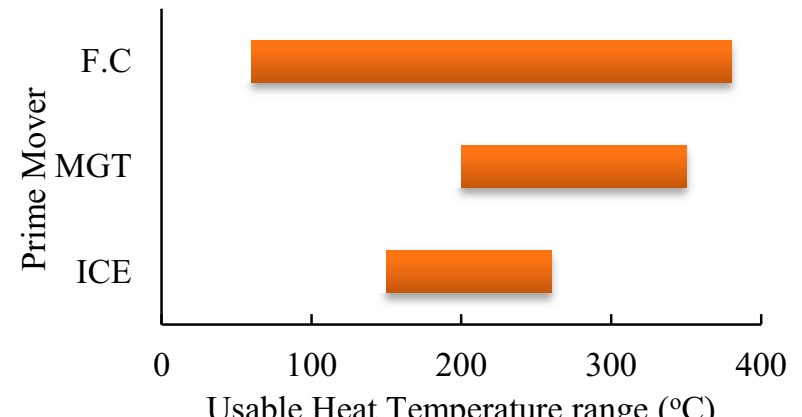

Figure 1. The range of useable exhaust temperature for several prime movers

Absorption chillers are well developed and mature technologies in the cooling industry compared to other cooling option [22]. Table 2 list features of several type of absorption chillers for integration in the TGS.

Through comprehensive view on the emission performances and economic benefits, MGT demonstrate better optimum prime movers for CGS and TGS. Even though, the efficiency is lower compared to both

Table 2. Features of Absorption Chiller Technologies [22]

\begin{tabular}{|c|c|c|}
\hline Absorption Chiller Type & Heat Input & COP \\
\hline LiBr- Water Single Effect & Hot water $70^{\circ} \mathrm{C}-90^{\circ} \mathrm{C}$,Steam 2-3bar & $\sim 0.7$ \\
\hline LiBr- Water Double Effect & Hot water $120^{\circ} \mathrm{C}-170^{\circ} \mathrm{C}$, Steam $4-8$ bar & $\sim 1.2$ \\
\hline LiBr- Water Triple Effect & Hot water $200^{\circ} \mathrm{C}-230^{\circ} \mathrm{C}$ & $1.4-1.5$ \\
\hline Water- $\mathrm{NH}_{3}$ Single Effect & Hot water $80^{\circ} \mathrm{C}-200^{\circ} \mathrm{C}$, Steam $2-16 \mathrm{bar}$ & $\sim 0.8$ \\
\hline Water- $\mathrm{NH}_{3}$ Double Effect & Hot water $170^{\circ} \mathrm{C}-220^{\circ} \mathrm{C}$, Steam $8-16 \mathrm{bar}$ & $0.8-1.2$ \\
\hline
\end{tabular}

\footnotetext{
a Corresponding author: rizdwan@hotmail.com
} 
Even though, the efficiency is lower compared to both reciprocating engines and fuel cells, proper integration in CGS and TGS will result in better overall efficiency in addition to feasibility on economics and environmental indicators

\section{Photovoltaic in Power Generation}

Photovoltaic (PV) is made of positive layer (P-dope) and negative layer (N-dope) semiconductors sandwiched together. Both layers are separated by a junction developed by internal electrical field that permits electrons and holes movement. When sunlight waveforms strike the photovoltaic (PV) cells surface the atom ionization process take place where the electrons are excited to P-dope and holes to $\mathrm{N}$-dope. This creates a voltage difference in between the layers and inducing an external circuit within which allows the electrons to move from P-dope to $\mathrm{N}$ dope[23]. PV panels are categorized into 3 main type of technologies which are PV panels with silicon crystalline structure, thin film PV technologies and PV made of compound semiconductors [24].

Beforehand, the atomic structure of the silicon based PV were either manufactured in monocrystalline (Mono$\mathrm{PV}$ ) or in multi-crystalline (Poly-PV) cells. There are several types of thin film technologies which are differentiated though the semiconductor materials that includes amorphous silicon (a-Si), copper indium gallium selenide (CiGS) and cadmium telluride (Cd-Te). Thin films PV are manufactured through depositing semiconductors on glass and stainless steel by using a spurting tool. Currently, Cd-Te PV displayed dominance by as much as $50 \%$ in thin film industries mainly due to lower production cost compared to CiGS type which has slightly higher efficiency[23-25].

The efficiency of respective various PV cells and modules are listed in Table 3 where concentrated multifunction PV acquires the highest efficiency due to stacking of different band gaps cells as well as utilization of mirror lenses to concentrate the light by a factor of 501000.There are two significant parameters accounted on estimating the PV output power which are the solar irradiation and ambient temperature. The correlation in Eq.(1) shows that high solar irradiation increases the PV output however, high ambient temperature decreases the efficiency [26].

$$
\begin{gathered}
P_{P V}(t)=\left[P_{\text {peak }}\left(\frac{G(t)}{G_{S T D}}\right)-\alpha_{t}\left(T_{c(t)}-T_{\text {STD }}\right)\right] \\
T_{c(t)}-T_{a m b(t)}=\frac{\text { NOTC- } 20}{800} G(t)
\end{gathered}
$$

where, $\mathrm{P}_{\mathrm{PV}}(\mathrm{t})$ and $\mathrm{P}_{\text {peak }}$ are instantaneous power and peak power in $\mathrm{W}, \mathrm{G}(\mathrm{t})$ and $\mathrm{G}_{\mathrm{STD}}$ are instantaneous and standard solar irradiation in $\mathrm{W} / \mathrm{m}^{2}$ respectively, $\mathrm{T}_{\mathrm{STD}}, T_{c(t)}$ NOTC are standard ambient temperature, cell temperature and nominal cell temperature in $\mathrm{K}$ respectively, and $\alpha_{t}$ is temperature coefficient . Through an innovative intervention programs initiated by the government in recent years, the price of installing a $3 \mathrm{~kW}_{\mathrm{p}}-10 \mathrm{~kW}_{\mathrm{p}}$ of $\mathrm{PV}$ arrays had reduced from $\mathrm{Rm} 55000 / \mathrm{kW}_{\mathrm{p}}$ as recorded in year 1990 to $\mathrm{Rm} 7000 / \mathrm{kW}_{\mathrm{p}}$ in year 2014

Table 3: The laboratory efficiency of respective PV cell and modules [27].

\begin{tabular}{|c|c|c|}
\hline \multirow{2}{*}{$\begin{array}{c}\text { Type of PV } \\
\text { Technology }\end{array}$} & \multicolumn{2}{|c|}{ Efficiency (\%) } \\
\cline { 2 - 3 } Mono- Crystalline PV & 25.0 & 22.9 \\
\hline Poly-Crystalline PV & 20.4 & 18.5 \\
\hline Cd-TE & 19.6 & 16.1 \\
\hline CIGS & 19.8 & 15.7 \\
\hline a-Si & 13.4 & 10.9 \\
\hline $\begin{array}{c}\text { Multi-Junction } \\
\text { (Concentrated) }\end{array}$ & 44.7 & 36.7 \\
\hline
\end{tabular}

The Germany emerged as the top leading country on the PV installation where the total generation $29,060 \mathrm{GWh}$ was by the end of 2012 followed by Italy, Belgium, Czech Republic, Greece and Australia and China is currently dominating the PV production industries [28, 29].

PV are interconnected forming an arrays for either standalone or grid tied applications. Narrowing the application to integrated building wise, PV had great potentials compared to other renewable energy system, based on criteria such as availability of energy source, convenience in integrated system and hybrid based system as well as due to the temporal correlations of electricity demand to the solar irradiations [30, 31]. Fig 3 illustrates the common configuration of PV in both standalone system and grid connected system (without back-up battery). In standalone system, batteries are utilized to store as well as distribute to the energy produced by the PV where charge controllers are installed to control the charging and discharging process. On the other hand, the simplest form of gird connected PV system without the battery storage system for back up purpose, only require inverters and metering units for system configurations. The end-users are allowed to inject clean power to the utility grid as well as consume electricity from the utility grid.

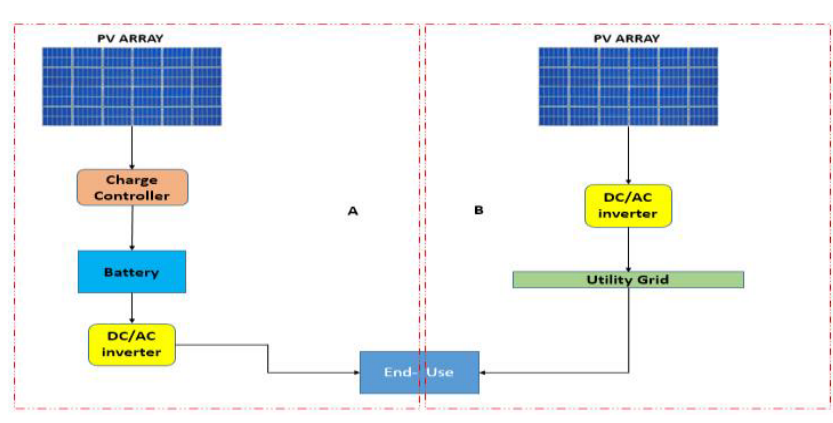

Figure 3: The figure shows the configuration of $\mathrm{PV}$ in standalone (A) mode and grid connected mode (B) 


\section{Photovoltaic in CGS/TGS}

Foremost, even though PV is emerging as one of the attractive renewable energy technology, the issue intermittency of PV output are yet to be resolved. Irregular weather patterns and lower conversion efficiency are considered as key factor to unfavorable installation of PV. On the other hand, application of CGS and TGS suffered several obstacles such as unpredictable thermal and power demand on typically application. In certain application, the both thermal and power demand are high in which the prime movers of the respective CGS and TGS failed to satisfy the respective demand. Furthermore, too frequent partial operation of certain prime movers to satisfy variable demands causes incomplete fuel combustion which lead to lower efficiency and higher emission. In additions, increasing fuel price also raises the issue on the reliability of CGS and TGS in power generations [32]. Hence, the hybridization of PV in CGS and TGS are one of the several sustainable solution that can be implemented to resolve the above issues. This section was intentional to summarize the design, analysis and optimization work perform under the PV-CGS/TGS scheme

\subsection{PV-CGS/TGS System Design}

Pearce et al [33] had provided extensive explanation on the concept of expanding the photovoltaic penetration through designing a PV-CGS/TGS hybrid based system. In his paper, the author had briefly idealized four generation concept of utilizing PV and in CGS and TGS from the simplest form of grid connected PV with CGS unit as back up to the most advanced PV-thermal integration with TGS unit. In addition, Carmeli et al [34], had designed a PV-CGS consisting of an internal combustion engine (ICE) where several system topologies and power flow control strategies were further analyzed. The simulation results were then employed during an experimental setup in Delebio, Italy to analyze the dynamic performances. The system operated in such a way that it was connected to the grid for normal applications and was also able to operate in a standalone mode during emergency.

There was also an assessment performed to investigate the combination of photovoltaic and solar thermal (PVT) in an integrated TGS system that included a natural gas prime mover, exhaust heat recovery unit and hybrid cooling system as well as storage tank [35]. Life cycle assessment optimization method was developed in order to analyze the environmental impact in three categories that namely global warming potential, acidification potential and respiratory effect potential. The result indicate that the energy efficiency is $51.66 \%$ and better performances is obtained through thermal load following strategy

\subsection{PV-CGS/TGS System Design}

Nosrat et al [36] compared the PV-CGS hybrid system with PV-TGS hybrid system through simulation in a self-developed software, PVTOM. The results interpreted from the literature show that the PV-TGS system had better economic and environmental performances that the PV-CGS system. Derewonko et al [37], studied on the feasibility of PV-CGS system where both rated power of $\mathrm{PV}$ and CGS were equivalent that is $1.2 \mathrm{~kW}$. The effect of climate and the operation time required by both power generation unit were analyzed extensively. The result shows that, PV only utilizes $50 \%$ of available solar energy due to losses suffered from cloudy weather.

In addition the author insisted on more studies to be performed on the PV-CGS system as the analysis displayed that the CGS prime mover were operated more than 20 hours daily to satisfy the load demand. The studies on economic analysis of PV-TGS for commercial office buildings as well as the optimization of the respective system were also studied by [38]. The analysis managed to summarize that the system was able to reduce the payback period compare to the separate power generation using CHS and PV as well as noting that the electric following strategy displayed better performances.

Ismail et al [39] had compared four utilization scenarios of PV and MGT in based on the Cost of Energy analysis (COE) for an application in Palestinian remote areas. The configurations compared were the stand alone PV system, MGT simple electricity generation, PV-MGT hybrid where MGT act as a backup power generator as well as a PV-MGT-CGS system. Through optimizing the tilt angle for PV, the results indicate that the PV-MGTCGS system has lower COE as compared to other system configurations where the COE is RM $0.95 / \mathrm{kWh}$.

\subsection{PV-CGS/TGS System Optimization}

Yang et al [40], had design an optimum sizing method for renewable energy system which included a PV and wind energy system integration with the MGT .The author had equipped an optimum sizing with simulated annealing algorithm to perform the optimization process and subsequently the results obtained were positive. Bando et al [41], had performed optimization studies on PV-CGS plant which included a battery storage system. The objective function for the optimization studies was the operation and maintenances cost (O\&M), primary energy consumption and the $\mathrm{CO}_{2}$ emission where the manipulated variable used in the studies was the size of PV arrays and the $\mathrm{CO}_{2}$ emission coefficient of the utility gird. Based on the simulation analysis, the PV-CGS system managed to reduce the $\mathrm{CO}_{2}$ emission and the primary energy consumption as a high PV capacity installation was utilized. Basrawi et al [42] had studied on the economic by manipulating different operation strategies on a PV-MGTTGS system that integrate auxiliaries component such as battery, thermal heat storage and boilers . The results show that power match strategies are economic as compared to the other operation strategies as well as the CCGT plant. However, the emission performances did not display positive result as compared to a CCGT plant due to lower efficiency during partial operation of MGT.

\section{Conclusion}

The simultaneous production of heating energy and power through CGS as well as cooling loads through TGS

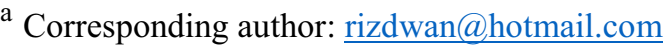


improve the overall system efficiency, reduce greenhouse gases emissions and offers economical energy generations in some cases. The selection of prime movers is crucial in obtaining top notch CGS and TGS where through literates and comparison, MGT is observe to serve better environmental and economic performances concurrently than other commercially available prime movers. The flaw existences in prime movers partial performances as well as varying energy demand lead to hydriziation of such CGS and TGS with renewable energy system. PV is one of the potential green technology which well fit in CGS and TGS hybrid based system as it is building integrated and resource abundancy. The integration of PV also assisted in resolving the intermittency problems of $\mathrm{PV}$ while improving the economic performances.

Based on the literature study, the integration of CGS or TGS and PV, require crucial attentions on the system topologies, sizing, weather conditions and as well as enduse demand where proper optimization should be perform. Analyzing a hybrid system with equipment of different working principles and individual properties, require proper control algorithm to optimize the energy flow. The control algorithm which is formulated based on dispatch strategy is important to avoid reduction in efficiency or system failure.

Hence, adequate optimization through the develop control algorithms should be perform prior to real life application. Extensive research work especially utilizing ICE as the prime movers were performed to design, analyze and optimize the hybrid system with proper dispatch strategy. Nevertheless, there are yet no specific control algorithm develop for CGS or TGS utilizing MGT in hybrid mode with PV. The development of algorithm for MGT-CGS or MGT-TGS and PV hybrid based system is essential as operation performance of MGT is highly dependent on ambient condition and energy demand. Hence, it is recommended on developing control algorithms for such system as it was simulated to provide better performances in both environmental and economical performances compare. Through the development, the reliability and flexibility of such system.

\section{Acknowledgement}

The author would like to acknowledge the authority of Malaysia Ministry of Education and University Malaysia Pahang upon the funding provide for the research under the grant (FGRS/2/2013/TK06/UMP/02/1) or RDU130133.

\section{References}

1. (IEA), I.E.A. Global energy-related emissions of carbon dioxide stalled in 2014. March 2015 [cited 201523 April]; Available from: http://www.iea.org/.

2. Ministry of Energy, C.a.M., Policy Framework and the Promotion of Cogeneration in Malaysia. 2013.

3. Cho, H., et al., Evaluation of CCHP systems performance based on operational cost, primary energy consumption, and carbon dioxide emission by utilizing an optimal operation scheme. Applied Energy, 2009. 86(12): p. 25402549.

4. Cho, H., A.D. Smith, and P. Mago, Combined cooling, heating and power: A review of performance improvement and optimization. Applied Energy, 2014. 136(0): p. 168-185.

5. Gelazanskas, L. and K.A.A. Gamage, Demand side management in smart grid: A review and proposals for future direction. Sustainable Cities and Society, 2014. 11(0): p. 22-30.

6. Kuhn, V., J. Klemeš, and I. Bulatov, MicroCHP: Overview of selected technologies, products and field test results. Applied Thermal Engineering, 2008. 28(16): p. 2039-2048.

7. Ahmad, S., M.Z.A.A. Kadir, and S. Shafie, Current perspective of the renewable energy development in Malaysia. Renewable and Sustainable Energy Reviews, 2011. 15(2): p. 897904.

8. Wong, S.L., et al., Recent advances of feed-in tariff in Malaysia. Renewable and Sustainable Energy Reviews, 2015. 41(0): p. 42-52.

9. Singh, G.K., Solar power generation by $P V$ (photovoltaic) technology: A review. Energy, 2013. 53: p. 1-13.

10. Nehrir, M.H., et al., A Review of Hybrid Renewable/Alternative Energy Systems for Electric Power Generation: Configurations, Control, and Applications. Sustainable Energy, IEEE Transactions on, 2011. 2(4): p. 392-403.

11. Holmberg, H., et al., Allocation of fuel costs and CO2-emissions to heat and power in an industrial CHP plant: Case integrated pulp and paper mill. Applied Energy, 2012. 93(0): p. 614-623.

12. Tian, J., et al., Measures and potentials of energysaving in a Chinese fine chemical industrial park. Energy, 2012. 46(1): p. 459-470.

13. Onovwiona, H.I. and V.I. Ugursal, Residential cogeneration systems: review of the current technology. Renewable and Sustainable Energy Reviews, 2006. 10(5): p. 389-431.

14. Bhatt, M.S., Mapping of general combined heat and power systems. Energy Conversion and Management, 2001. 42(1): p. 115-124.

15. Chicco, G. and P. Mancarella, Distributed multigeneration: A comprehensive view. Renewable and Sustainable Energy Reviews, 2009. 13(3): p. 535-551.

16. Schicktanz, M.D., J. Wapler, and H.M. Henning, Primary energy and economic analysis of combined heating, cooling and power systems. Energy, 2011. 36(1): p. 575-585.

17. P.A.Pilavachi, Power Generation with Gas Turbine System and Combined Heat and Power Applied Thermal Engineering 2000.

18. Bruno, J. and A. Coronas. Distributed generation of energy using micro gas turbines: polygeneration systems and fuel flexibility. in Proceedings of the international conference on renewable energy and power quality (ICREPQ'04). 2004. 
19. Ismail, M.S., M. Moghavvemi, and T.M.I. Mahlia, Current utilization of microturbines as a part of a hybrid system in distributed generation technology. Renewable and Sustainable Energy Reviews, 2013. 21(0): p. 142-152.

20. $\mathrm{Yu}, \mathrm{X}$., Z. Jiang, and A. Abbasi. Dynamic modeling and control design of microturbine distributed generation systems. in Electric Machines and Drives Conference, 2009. IEMDC'09. IEEE International. 2009. IEEE.

21. Steven Brown, J. and P.A. Domanski, Review of alternative cooling technologies. Applied Thermal Engineering, 2014. 64(1-2): p. 252-262.

22. Jradi, M. and S. Riffat, Tri-generation systems: Energy policies, prime movers, cooling technologies, configurations and operation strategies. Renewable and Sustainable Energy Reviews, 2014. 32(0): p. 396-415.

23. Meral, M.E. and F. Dinçer, A review of the factors affecting operation and efficiency of photovoltaic based electricity generation systems. Renewable and Sustainable Energy Reviews, 2011. 15(5): p. 2176-2184.

24. El Chaar, L., L.A. lamont, and N. El Zein, Review of photovoltaic technologies. Renewable and Sustainable Energy Reviews, 2011. 15(5): p. 2165-2175.

25. Parida, B., S. Iniyan, and R. Goic, A review of solar photovoltaic technologies. Renewable and Sustainable Energy Reviews, 2011. 15(3): p. 1625-1636.

26. Khatib, T. and W. Elmenreich, Novel simplified hourly energy flow models for photovoltaic power systems. Energy Conversion and Management, 2014. 79: p. 441-448.

27. ISE. Photovoltaics Report. 24 October 2014 [cited 201523 April]; Available from: www.ise.fraunhofer.de.

28. Kumar Sahu, B., A study on global solar PV energy developments and policies with special focus on the top ten solar PV power producing countries. Renewable and Sustainable Energy Reviews, 2015. 43(0): p. 621-634.

29. Sener, C. and V. Fthenakis, Energy policy and financing options to achieve solar energy grid penetration targets: Accounting for external costs. Renewable and Sustainable Energy Reviews, 2014. 32(0): p. 854-868.

30. Brandoni, C. and M. Renzi, Optimal sizing of hybrid solar micro-CHP systems for the household sector. Applied Thermal Engineering, 2015. 75(0): p. 896-907.

31. Mohammed, Y.S., M.W. Mustafa, and N. Bashir, Hybrid renewable energy systems for off-grid electric power: Review of substantial issues. Renewable and Sustainable Energy Reviews, 2014. 35(0): p. 527-539.

32. Immovilli, F., et al. Solar Trigeneration for Residential Applications, a Feasible Alternative to Traditional Micro-Cogeneration and Trigeneration Plants. in Industry Applications
Society Annual Meeting, 2008. IAS '08. IEEE. 2008.

33. Pearce, J.M., Expanding photovoltaic penetration with residential distributed generation from hybrid solar photovoltaic and combined heat and power systems. Energy, 2009. 34(11): p. 19471954.

34. Carmeli, M.S., et al. Hybrid PV-CHP distributed system: Design aspects and realization. in Clean Electrical Power, 2009 International Conference on. 2009.

35. Wang, J., et al., Life cycle assessment (LCA) optimization of solar-assisted hybrid CCHP system. Applied Energy, 2015. 146(0): p. 38-52.

36. Nosrat, A.H., L.G. Swan, and J.M. Pearce, Improved performance of hybrid photovoltaictrigeneration systems over photovoltaic-cogen systems including effects of battery storage. Energy, 2013. 49: p. 366-374.

37. Derewonko, P. and J.M. Pearce. Optimizing design of household scale hybrid solar photovoltaic + combined heat and power systems for Ontario. in Photovoltaic Specialists Conference (PVSC), 2009 34th IEEE. 2009.

38. Jiang-Jiang, W., et al. Economic analysis and optimization design of a solar combined cooling heating and power system in different operation strategies. in Industrial Electronics and Applications (ICIEA), 2012 7th IEEE Conference on. 2012.

39. Ismail, M.S., M. Moghavvemi, and T.M.I. Mahlia, Design of an optimized photovoltaic and microturbine hybrid power system for a remote small community: Case study of Palestine. Energy Conversion and Management, 2013. 75(0): p. 271-281.

40. Yang, Y., W. Pei, and Z. Qi. Optimal sizing of renewable energy and $\mathrm{CHP}$ hybrid energy microgrid system. in Innovative Smart Grid Technologies-Asia (ISGT Asia), 2012 IEEE. 2012. IEEE.

41. Bando, S., et al. Optimal Operation Planning of a Photovoltaic-Cogeneration-Battery Hybrid System. in Power System Technology, 2006. PowerCon 2006. International Conference on. 2006.

42. Basrawi, F., T. Yamada, and S.y. Obara, Economic and environmental based operation strategies of a hybrid photovoltaic-microgas turbine trigeneration system. Applied Energy, 2014. 121(0): p. 174-183. 